\title{
$\mathrm{Al}-\mathrm{Mg}-\mathrm{Si}$ 合金における \\ 2 段時効のクラスタ形成と機械的性質への影響
}

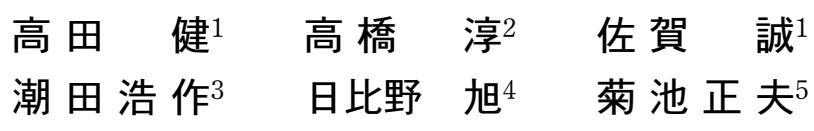

\author{
1新日本製鐵株式会社鉄鋼研究所 \\ 2 新日本製鐵株式会社先端技術研究所 \\ 3 新日本製鐵株式会社技術開発本部 \\ 4古河スカイ株式会社技術研究所 \\ 5九州大学鉄鋼リサーチセンター
}

J. Japan Inst. Metals, Vol. 76, No. 12 (2012), pp. 677-683 (C) 2012 The Japan Institute of Metals

\section{Influence of Two-Step Aging on Cluster Formation and Tensile Property in Al-Mg-Si Alloy}

Ken Takata ${ }^{1}$, Jun Takahashi², Makoto Saga ${ }^{1}$,

Kohsaku Ushioda ${ }^{3}$, Akira Hibino ${ }^{4}$ and Masao Kikuchi ${ }^{5}$

${ }^{1}$ Steel Research Laboratories, Nippon Steel Corporation, Futtsu 293-8511

${ }^{2}$ Advanced Technology Research Laboratories, Nippon Steel Corporation, Futtsu 293-8511

${ }^{3}$ Technical Development Bureau, Nippon Steel Corporation, Futtsu 293-8511

${ }^{4}$ Technical Research Center, Furukawa-Sky Aluminum Corporation, Fukaya 366-8511

${ }^{5}$ Research Center for Steel, Kyushu University, Fukuoka 819-0395

The change of the state of Mg-Si cluster with aging time at $303 \mathrm{~K}$ and $323 \mathrm{~K}$ after pre-aging at $363 \mathrm{~K}$ was studied by means of tensile test focusing on yield stress, 3DAP (3 Dimensional Atom Probe) and DSC (Differential Scanning Calorimetry) measurement. $\mathrm{Mg}-\mathrm{Si}$ clusters formed during isothermal aging at the temperature of $363 \mathrm{~K}$ after solution treatment were different from the ones formed at the temperatures of $303 \mathrm{~K}$ and $323 \mathrm{~K}$. During aging at $303 \mathrm{~K}$ and $323 \mathrm{~K}$ following pre-aging at $363 \mathrm{~K}$, the cluster that was once formed at $363 \mathrm{~K}$ grew in size together with the new nucleation of another type of cluster formed at $303 \mathrm{~K}$ and $323 \mathrm{~K}$. The increment of yield stress with aging time at $303 \mathrm{~K}$ and $323 \mathrm{~K}$ after pre-aging at $363 \mathrm{~K}$ was greater than the one without pre-aging at $363 \mathrm{~K}$. This was considered to stem from the fact that the cluster formed during pre-aging at $363 \mathrm{~K}$ further grows during aging at $303 \mathrm{~K}$ and $323 \mathrm{~K}$ but at the same time the another type of cluster is supposed to newly nucleate and grow at $303 \mathrm{~K}$ or $323 \mathrm{~K}$ after pre-aging, both of which are inferred to contribute to the larger increase in yield strength.

(Received August 16, 2012; Accepted October 1, 2012; Published December 1, 2012)

Keywords: aluminum-magnesium-silicon alloy, magnesium-silicon cluster, two-step aging, 3 dimensional atom probe (3DAP), differential scanning calorimetry (DSC), yield stress

1. 序論

近年，自動車用パネル部材には，軽量化の要求から約 448 $\mathrm{K}$ での塗装焼付け熱処理にて良好な析出強化が得られる $\mathrm{Al}-$ $\mathrm{Mg}-\mathrm{Si}$ 合金が使用される傾向にある.自動車向けのこの合 金は，析出強化を得るために溶体化熱処理後に $448 \mathrm{~K}$ 以下 での予備熱処理が施され，その後室温に保持される．この室 温保持中に合金中の析出状態は変化し, それに伴い強度が増 加する可能性がある. 自動車パネル向けの新合金開発には, このような予備熱処理後の室温保持中の析出状態変化を把握 する必要がある。

$\mathrm{Al}-\mathrm{Mg}-\mathrm{Si}$ 合金における $448 \mathrm{~K}$ 以下での析出過程に関する 従来の研究結果を Table 1 に示す ${ }^{1-5)}$. $373 \mathrm{~K}$ 以下では $\mathrm{Mg}$

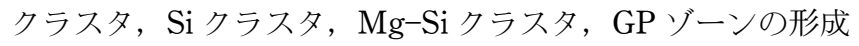
が報告されている．ここでの GP ゾーンとは透過電子顕微鏡 (Transmission Electron Microscope: TEM)にてコントラス トを示す $2 \mathrm{~nm}$ 程度のサイズを持つ $\mathrm{Mg}-\mathrm{Si}$ クラスタを意味

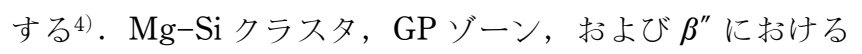
$\mathrm{Mg} / \mathrm{Si}$ 比は合金組成の $\mathrm{Mg} / \mathrm{Si}$ に等しい。一方， $\beta^{\prime}$ 中および

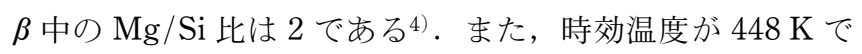
は, $\beta^{\prime \prime}$ と短時間保持にて GP ゾーンが形成される.

Murayama らは, 溶体化熱処理と $448 \mathrm{~K} に て 10.8 \mathrm{ks}$ の熱 処理の間に $6048 \mathrm{ks}$ の室温保持を施すと $\beta^{\prime \prime}$ の形成は遅れる ことと ${ }^{3)}$, 溶体化熱処理と $448 \mathrm{~K} に て 36 \mathrm{ks}$ の熱処理の間に 室温にて $6048 \mathrm{ks}$ 保持を施した場合に形成される $\beta^{\prime \prime}$ の分布 密度は, 同じ熱処理の前に $343 \mathrm{~K} に て 57.6 \mathrm{ks}$ 保持を施した 場合に形成される $\beta^{\prime \prime}$ の分布密度よりも小さいことを報告し 
Table 1 Precipitation sequence in $\mathrm{Al}-\mathrm{Mg}-\mathrm{Si}$ alloy.

\begin{tabular}{|c|c|c|c|c|c|}
\hline \multicolumn{2}{|c|}{ Aging condition } & \multirow{2}{*}{ Alloy (mass\%) } & \multirow{2}{*}{ Phase } & \multirow{2}{*}{ Measurement } & \multirow{2}{*}{ Ref. } \\
\hline Temperature, $T / \mathrm{K}$ & Aging time & & & & \\
\hline \multirow{6}{*}{448} & $259.2 \mathrm{ks}$ & $\mathrm{Al}-0.8 \mathrm{Mg}-0.79 \mathrm{Si}$ & $\beta^{\prime \prime}$ & TEM & 1) \\
\hline & $32.4 \mathrm{ks}$ & $\mathrm{Al}-0.58 \mathrm{Mg}-0.32 \mathrm{Si}, \mathrm{Al}-0.53 \mathrm{Mg}-0.71 \mathrm{Si}$ & $\beta^{\prime \prime}$ & TEM & 2) \\
\hline & $10.8 \mathrm{ks}$ & $\mathrm{Al}-0.53 \mathrm{Mg}-0.71 \mathrm{Si}$ & $\beta^{\prime \prime}$ & TEM & 3) \\
\hline & $1.8 \mathrm{ks}$ & $\mathrm{Al}-0.53 \mathrm{Mg}-0.71 \mathrm{Si}$ & GP zone & TEM & 3) \\
\hline & $1.8 \mathrm{ks}$ & $\mathrm{Al}-0.57 \mathrm{Mg}-0.31 \mathrm{Si}, \mathrm{Al}-0.53 \mathrm{Mg}-0.66 \mathrm{Si}$ & GP zone & TEM & 4) \\
\hline & $1.8 \mathrm{ks}$ & $\mathrm{Al}-0.8 \mathrm{Mg}-0.79 \mathrm{Si}$ & $\beta^{\prime \prime}$ & TEM & 1) \\
\hline \multirow[t]{2}{*}{373} & $3.6 \mathrm{ks}$ & $\mathrm{Al}-0.95 \mathrm{Mg}-0.81 \mathrm{Si}$ & $\mathrm{Mg}-\mathrm{Si}$ cluster & 3DAP & 5) \\
\hline & $600 \mathrm{~s}$ & $\mathrm{Al}-0.95 \mathrm{Mg}-0.81 \mathrm{Si}$ & $\mathrm{Mg}-\mathrm{Si}$ cluster & 3DAP & 5) \\
\hline 343 & $57.6 \mathrm{ks}$ & $\mathrm{Al}-0.57 \mathrm{Mg}-0.31 \mathrm{Si}, \mathrm{Al}-0.53 \mathrm{Mg}-0.66 \mathrm{Si}$ & GP zone & TEM, 3DAP & 4) \\
\hline \multirow{4}{*}{ RT } & $7.88 \times 10^{4} \mathrm{ks}$ & $\mathrm{Al}-0.95 \mathrm{Mg}-0.81 \mathrm{Si}$ & Mg-Si cluster & 3DAP & 5) \\
\hline & $6048 \mathrm{ks}$ & $\mathrm{Al}-0.53 \mathrm{Mg}-0.71 \mathrm{Si}$ & Mg-Si cluster, Mg-cluster, Si-cluster & APFIM & 3) \\
\hline & $6048 \mathrm{ks}$ & $\mathrm{Al}-0.57 \mathrm{Mg}-0.31 \mathrm{Si}, \mathrm{Al}-0.53 \mathrm{Mg}-0.66 \mathrm{Si}$ & $\mathrm{Mg}-\mathrm{Si}$ cluster, $\mathrm{Mg}$-cluster, $\mathrm{Si}-$ cluster & 3DAP & 4) \\
\hline & $2419 \mathrm{ks}$ & $\mathrm{Al}-0.95 \mathrm{Mg}-0.81 \mathrm{Si}$ & $\mathrm{Mg}-\mathrm{Si}$ cluster & 3DAP & 5) \\
\hline \multicolumn{2}{|c|}{ As-quench } & $\mathrm{Al}-0.8 \mathrm{Mg}-0.79 \mathrm{Si}$ & Mg-cluster & APFIM & 1) \\
\hline
\end{tabular}

ている4). 彼らは，これらの結果から， $343 \mathrm{~K}$ 以上の保持に て形成される GP ゾーンすなわち粗大な $\mathrm{Mg}-\mathrm{Si}$ クラスタは $448 \mathrm{~K}$ の熱処理にて $\beta^{\prime \prime}$ へ成長するが，室温保持にて形成 される $\mathrm{Mg}-\mathrm{Si}$ クラスタは $\beta^{\prime \prime}$ へは成長せず，これらクラスタ は異なる種類であると結論している4).それゆえ， $343 \mathrm{~K}$ 以 上の温度の予備熱処理を施し，続いて室温時効を施した場合 には， $343 \mathrm{~K}$ 以上の予備熱処理にて形成された $\mathrm{Mg}-\mathrm{Si}$ クラ スタとは異なるクラスタが室温保持にて形成されると予想さ れる．著者らは以前， $363 \mathrm{~K}$ の予備熱処理を施した後の室温 保持での降伏応力の増大挙動が予備熱処理を施さない場合の それと異なること6), および予備熱処理後のクラスタの形態 変化の調查7)を報告した。しかし，予備熱処理後の室温時効 における 2 種類のクラスタ，すなわち $363 \mathrm{~K}$ で形成された クラスタ，およびその後の室温時効で形成されるクラスタの 大きさや分布密度の状態变化と機械的性質との関係について は明確ではない. 本研究の目的はこの点を明らかにすること にある・

クラスタの大きさと分布密度の変化は, 転位との相互作用 を介して, 引張試験に打ける降伏応力に影響することが予想 される. 一般に転位の移動障害による降伏応力の増加代 $\Delta \sigma$ は以下の式で表すことができる ${ }^{8,9)}$.

$$
\Delta \sigma=M F /(b L)
$$

ここで, $M, F, b, L$ はそれぞれ, Taylor 因子, 析出物の転位 への最大障害力, バーガースベクトル，転位をピン止めする 析出物間距離である.式 (1) で定義される降伏応力におい て析出物の構造に制約はないため, 式 (1) はクラスタに対 しても成り立つことが考えられる。 それゆえ，クラスタの分 布密度が高くなれば $L$ の值は小さくなり降伏応力值は上昇 する。また，クラスタが大きくなれば，Lは小さくなり，転 位への抵抗力すなわち $F$ の值が増大し降伏応力值は上昇す ると予想される. したがって, 室温保持中のクラスタの大き さと分布密度の変化は降伏応力の変化に現れることが予想さ れる，なお，Gを剛性率として $F>G b^{2}$ であれば，転位はク ラスタに対してオロワンループを残して通過し， $F \leqq G b^{2}$ で あれば，転位はクラスタをカットして通過する。しかし，い
ずれの場合でも降伏応力は式 (1)を用いて表現できる.ク ラスタの形成量の変化の調査や種類の判別には DSC (Differential Scanning Calorimetry) 測定が有効である。ま た，クラスタの大きさと分布密度は 3 次元アトムプローブ (3 Dimensional Atom Probe: 3DAP)を用いて測定できる.

本研究では $\mathrm{Al}-\mathrm{Mg}-\mathrm{Si}$ 合金において, $363 \mathrm{~K}$ 保持の予備熱 処理にてクラスタを形成させ，その後， $303 \mathrm{~K}$ と $323 \mathrm{~K}$ に 保持した場合のクラスタの状態変化を, 引張試験, DSC, 3DAP, TEM を用いて調査した。最初に，303, $323 \mathrm{~K}$ ，打よ び $363 \mathrm{~K}$ での等温保持時効 (1 段時効)におけるクラスタ状態 の変化を調査した。次に, $363 \mathrm{~K}$ の予備熱処理後に $303 \mathrm{~K}$ あるいは $323 \mathrm{~K}$ での保持を実施する 2 段時効を行いクラス タ状態の時間変化と引張特性の变化を調査し, 従来解明され ていない高温の熱処理後の室温時効時のクラスタ形成挙動の 解明を行うことで， 2 段時効の機械的性質に及ぼす影響解明 を行った。

\section{2. 実験}

\section{1 試 料}

試料は $\mathrm{Mg}$ と $\mathrm{Si} と も に 0.7$ mass\%含有する $\mathrm{Al}-\mathrm{Mg}-\mathrm{Si}$ 合 金を使用した。工場にて，鋳造，熱間圧延，冷間圧延を経て 厚さ $1 \mathrm{~mm}$ の板を製造した. 続いて，実験室にて，ソルトバ スによる $803 \mathrm{~K} に て 60 \mathrm{~s}$ 間保持する溶体化熱処理後，水焼 き入れを行った．水焼き入れした試料は，以下に述べる時効 処理以外は液体窒素に浸漬して保管した。水焼入れ後の 1 部の試料は, 乾燥炬による $303 \mathrm{~K}$, あるいはオイルバスによ る $323 \mathrm{~K}$ と $363 \mathrm{~K}$ の等温時効 (1 段時効)を行った．他の試 料は, オイルバスにより $363 \mathrm{~K} に て 7.2 \mathrm{ks}$ から $43.2 \mathrm{ks}$ まで の予備熱処理を行い, 続いて乾燥炉による $303 \mathrm{~K}$ 時効ある いはオイルバスによる $323 \mathrm{~K}$ 時効の 2 段時効を行った.

\section{2 引張試験方法, TEM 観察方法, および 3DAP と DSC によるクラスタの解析方法}

降伏応力は, Autograph AG-10T(侏島津製作所)を用いた 
引張試験により求めた。試験は室温にて実施し, 試験片 (JIS5 号試験片)の引張り方向は素材の圧延方向と平行であ り，そのゲージ長さは $50 \mathrm{~mm}$ である. 引張速度は, 歪が $1 \%$ 以下では $1 \mathrm{~mm} / \mathrm{min}$ である. $0.2 \%$ 耐力值を降伏応力と した．TEM 試料には，時効を施した板材試料の両表面より $80 \mu \mathrm{m}$ 厚まで研磨を行い, その後, 両面ジェット電解研磨 を使用して穴をあけた薄膜試料を用いた。使用したTEM は 侏日立製作所製 HF-2000であり，加速電圧は $200 \mathrm{kV}$ であ る.

クラスタの大きさ (構成原子数) の平均值と分布密度は 3DAP (Oxford nanoScience Ltd, UK) を用い，粒子解析法10) により求めた。粒子解析法に使用する 2 つの゚ラメータ $d$ と $N$ の最適值は今まで定義されておらず任意性が残り, 本 研究では, 我々の過去の知見をもとに $d=1.0 \mathrm{~nm}$ と $N=10$ を最適值として用いた。原子の検出率は $50 \%$ であるため, 構成原子数は粒子解析により得られたそれの 2 倍の值を採 用した。測定時の試料温度は $20 \mathrm{~K}$ 以下であり，測定原子数 は 20 万以上である. 測定では 3 ヶ所以上の異なる場所から 取り出した試料にて, 得られた測定データのバラツキが少な いことを確認した上で，1 つ以上の解析体積が $7 \mathrm{~nm} \times 7 \mathrm{~nm}$ $\times 70 \mathrm{~nm}$ である試料のデータの数值を採用した.

DSC 測定では，侏リガク製の DSC8230 機器を用いた。 試料の測定温度範囲は室温から $773 \mathrm{~K}$ であり，その昇温速 度は $20 \mathrm{~K} / \mathrm{min}$ とした。

\section{3. 結 果 と考察}

\section{1 等温保持時効}

Fig. 1 は As-quench 材, 303, 323, $363 \mathrm{~K}$ 保持材にて得ら れた DSC カーブを示す. Edwards らは, Al-0.8 mass\% $\mathrm{Mg}-$ 0.79 mass \% Si 合金における溶体化熱処理後の DSC カーブ にて，低温側から， Mg-Si クラスタの形成， $\beta^{\prime \prime}$ の形成， $\beta^{\prime}$ の形成の順に，それらの発熱ピークが出現すると報告し ている1)。彼らの DSC 測定での昇温速度は $5 \mathrm{~K} / \mathrm{min}$ であ り，本研究での $20 \mathrm{~K} / \mathrm{min}$ と異なり，発熱および吸熱の温度

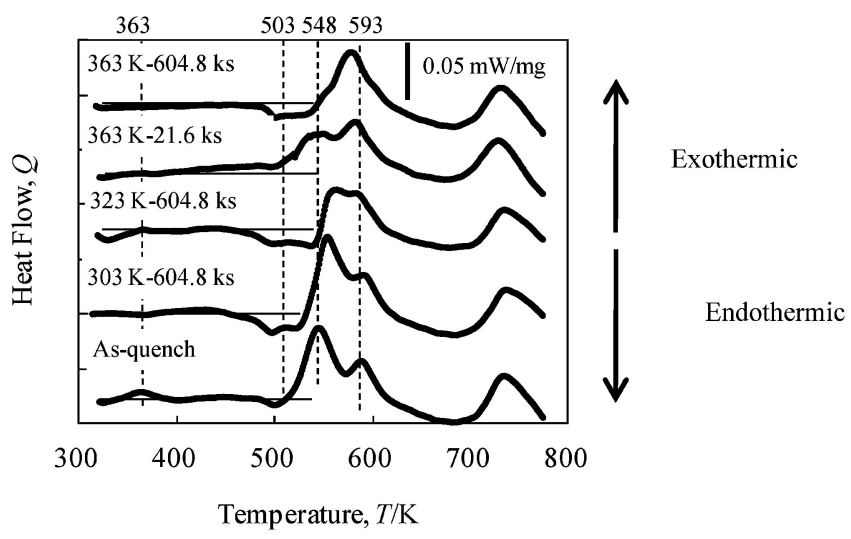

Fig. 1 Differential scanning calorimetry (DSC) thermograms of specimens subjected to quenching (as quench) and isothermal aging at $303 \mathrm{~K}$ for $604.8 \mathrm{ks}$, at $323 \mathrm{~K}$ for $604.8 \mathrm{ks}$, at $363 \mathrm{~K}$ for $21.6 \mathrm{ks}$ and at $363 \mathrm{~K}$ for $604.8 \mathrm{ks}$ after solution heat treatment in a salt bath.
は異なる可能性がある。しかし，発熱抢よび吸熱現象の順番 は変わらない。したがって, As-quench 材の DSC カーブに 見られる $363,548 \mathrm{~K}$ ，および $593 \mathrm{~K}$ の発熱反応は，それぞ れ, クラスタの形成, $\beta^{\prime \prime}$ の形成, 拈よび $\beta^{\prime}$ の形成を示すと 考えられる。一方, $503 \mathrm{~K}$ の微少な吸熱量は $363 \mathrm{~K}$ の発熱 ピークに対応するクラスタの溶解によるものと推定される. なお，本研究での DSC 測定では $\mathrm{Mg}$ クラスタ， $\mathrm{Si}$ クラスタ， $\mathrm{Mg}-\mathrm{Si}$ クラスタを分離して観察されていない。後述する 3DAP の結果から，得られたクラスタの殆どは $\mathrm{Mg}-\mathrm{Si} ク ラ$ スタと推定される. Murayama らは $343 \mathrm{~K}$ 以上で形成され る $\mathrm{Mg}-\mathrm{Si}$ クラスタと $343 \mathrm{~K}$ 以下の保持で形成される $\mathrm{Mg}-\mathrm{Si}$ クラスタは異なることを指摘している4). Serizawa らも 2 種 類のクラスタの存在を報告し，それらをクラスタ I とクラス タII と呼んでいるが5)，DSC 測定にて得られるそれらの形成 熱のピーク温度は後述する本研究にて得られたそれらと異な る、それゆえ，本論文ではそれぞれを高温クラスタ，および 低温クラスタと呼ぶ.

$303 \mathrm{~K}$ にて $604.8 \mathrm{ks}$ 保持した材料では，As-quench 材に 比べて, $363 \mathrm{~K}$ での発熱ピークは消失し, $503 \mathrm{~K}$ での吸熱量 が増大している。これは， $303 \mathrm{~K}$ にて $604.8 \mathrm{ks}$ 保持の間 に, 過飽和の固溶 $\mathrm{Mg}$ 原子と固溶 $\mathrm{Si}$ 原子が低温クラスタ形 成をしたことを示す. $323 \mathrm{~K} に て 604.8 \mathrm{ks}$ 保持した材料に おいても，As-quench 材に比べて，363 K での発熱ピーク は消失し， $503 \mathrm{~K}$ での吸熱量が増大している。したがって， $323 \mathrm{~K}$ 保持においても $303 \mathrm{~K}$ 保持と同様に, 過飽和の固溶 $\mathrm{Mg}$ 原子と固溶 $\mathrm{Si}$ 原子が低温クラスタを形成したと言える. $363 \mathrm{~K}$ にて $21.6 \mathrm{ks}$ 保持した材料においては，As-quench 材 に比べて, $363 \mathrm{~K}$ での発熱ピークは消失し， $548 \mathrm{~K}$ での発熱 量が大きく減少し， $593 \mathrm{~K}$ での発熱量のピークが低温側に移 動している．同温度にて $604.8 \mathrm{ks}$ 保持した材料では， $548 \mathrm{~K}$ での発熱量はさらに減少している. DSC 測定の前に $\beta "$ が既 に形成される場合には， $548 \mathrm{~K}$ での発熱ピークは減少する. しかし， $363 \mathrm{~K}$ の保持では $\beta^{\prime \prime}$ は形成されず，高温クラスタ が形成されるので4,5), $363 \mathrm{~K}$ での予備時効に伴う $548 \mathrm{~K}$ の 発熱ピークの減少は高温クラスタ形成と関係があるものと推 察される，すなわち，高温クラスタが形成されるとそれを核 に $\beta^{\prime \prime}$ の形成が容易になるので, $364 \mathrm{~K}$ での時効時間ととも にDSC 測定中の $\beta^{\prime \prime}$ の形成量が増加し $548 \mathrm{~K}$ での発熱ピー クが低下したと考えた。

Fig. 2 は $363 \mathrm{~K}$ にて $21.6 \mathrm{ks}$ 保持および $2592 \mathrm{ks}$ 保持した 材料の 3DAP にて得られた $\mathrm{Mg}$ 原子と $\mathrm{Si}$ 原子の 3DAP マッ プを示す．粒子解析後の原子マップを示した Fig. 2 (b) と (d)にて Mg と Si を含むクラスタが明瞭に観察された。観察

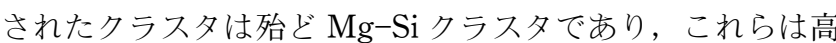
温クラスタと考えられる. $21.6 \mathrm{ks}$ 保持材および $2592 \mathrm{ks}$ 保 持材の高温クラスタの分布密度と平均構成原子数は, それぞ れ， $4 \times 10^{24} \mathrm{~m}^{-3}$ と 28 個抢よび $4 \times 10^{24} \mathrm{~m}^{-3}$ と 120 個であ り，保持時間によりクラスタの分布密度はほとんど変化せず その大きさが増大している。したがって，363 K 保持では， 新規に $\mathrm{Mg}-\mathrm{Si}$ クラスタの核を形成することはなく，初期に 形成された高温クラスタがその構成原子数を増大させる形で 成長すると言える。また，高温クラスタの分布密度から，ク 
(a)

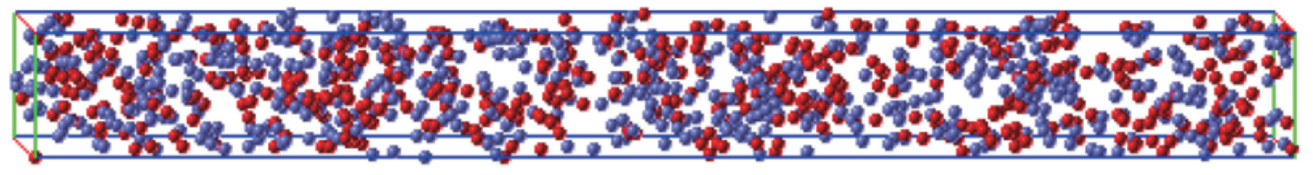

(b)

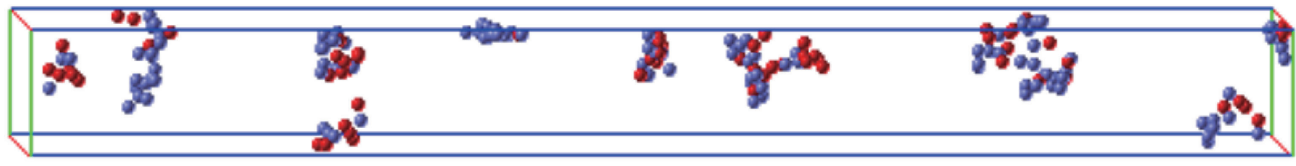

(c)

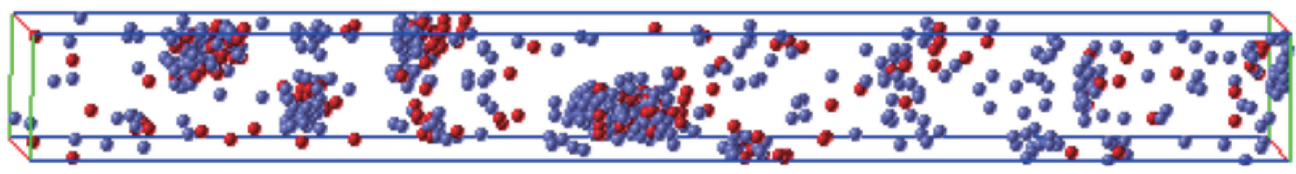

(d)

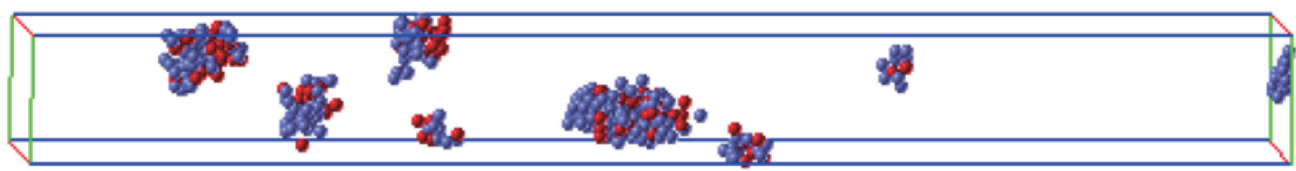

$10 \mathrm{~nm}$

Fig. 2 3D atom maps of $\mathrm{Mg}$ and $\mathrm{Si}$ of specimens aged at $363 \mathrm{~K}$. (a), (b) after aging for $21.6 \mathrm{ks}$; (c), (d) after aging for $2592 \mathrm{ks}$; in (a) and (c), all the Mg and Si atoms detected are shown by blue and red points, respectively; and in (b) and (d), only the atoms in the clusters are shown based on the particles analysis with $d=1.0 \mathrm{~nm}$ and $N=10$.

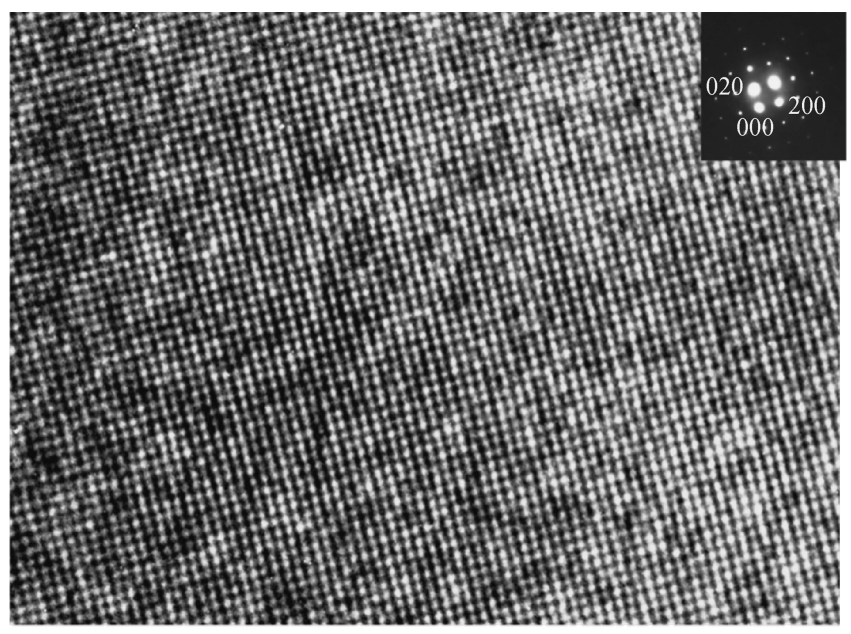

$1 \mathrm{~nm}$

Fig. 3 A HRTEM image taken at the [001] $\mathrm{Al}$ zone axis and a diffraction pattern taken at [001] in a selected area of an alloy specimen aged at $363 \mathrm{~K}$ for $4320 \mathrm{ks}$. No contrast corresponding to precipitate was observed. The dark regions seen in this image is not due to any precipitation nor reconstruction of lattice but seems to be due to the difference of thickness of membrane.

ラスタ中心間の平均間隔は約 $10 \mathrm{~nm}$ と見積もられた. Fig. 3 は $363 \mathrm{~K}$ にて $2592 \mathrm{ks}$ 保持した材料の高分解 TEM 像を示 す. Fig. 3 中の視野面積には Fig. 2 で示されたクラスタは 十分存在している. しかし, 母相と大きく構造の異なる析出 物を見出すことはできなかった.

\subsection{2 段時効熱処理}

Fig. 4 は $363 \mathrm{~K}$ にて 7.2, 14.4, 21.6, $43.2 \mathrm{ks}$ 保持の予備熱 処理後の $303 \mathrm{~K}$ 時効における降伏応力の変化を, 予備熱処 理を施さない材料のそれとともに示したものである.

予備熱処理を施さない材料にて見られる初期の急激な降伏
応力の増大は, 溶体化熱処理後の水焼き入れにて形成された 大量の焼入れ空孔を消費した急激な低温クラスタの核形成， すなわち式 (1)に打けるLの急激な減少によるものと考え られる.急激な降伏応力の増大以降の降伏応力の緩やかな増 大は，低温クラスタの成長，すなわち，式 ( 1 )における $L$ の減少と $F$ の増大によるものと推察される.

予備熱処理材の初期降伏応力値は予備熱処理時間の増大に したがい上昇する. Fig. 2 に示した $363 \mathrm{~K}$ 保持での 3DAP 解析結果から, これら初期降伏応力值の上昇は, 主に予備熱 処理における高温クラスタの成長に起因するものであり，式 （1）に打けるFの増大によるものと考えられる．予備熱処 理材に抢ける予備熱処理後の $303 \mathrm{~K}$ 時効での降伏応力值の 上昇速度は予備熱処理を施さない材料の急激な増大以降のそ れと比べて大きい。予備熱処理材には高温クラスタと低温ク ラスタの 2 種類のクラスタが存在すると考えられ，予備熱 処理を施さない材料には低温クラスタのみが存在する. 降伏 応力值の上昇速度の差はこれらクラスタの状態変化の違いに よるものと考えられる. クラスタの降伏応力への寄与は高温 クラスタの寄与分と低温クラスタの寄与分に分けて考えるこ とができる. Fig. 4 に見られる予備熱処理を施さない材料で は, 高温クラスタは存在しないので, その降伏応力の増加 は, 固溶原子量の減少による低下分と低温クラスタの成長に よる増分の和によると考えられる。一方，予備熱処理材で は, 高温クラスタは存在し, その降伏応力の増加速度が予備 熱処理を施さない材料に比べて大きいことは, 高温クラスタ の降伏応力への寄与量が時間とともに変化している可能性, すなわち予備熱処理後の $303 \mathrm{~K}$ 保持では, 低温クラスタの 成長に加えて高温クラスタの大きさ，あるいはその分布密度 が変化していることが示唆される.

Fig. 5 は， $363 \mathrm{~K}$ にて $21.6 \mathrm{ks}$ 保持の予備熱処理後， 303 $\mathrm{K}$ の時効処理あるいは $323 \mathrm{~K}$ の時効処理を施した材料から 


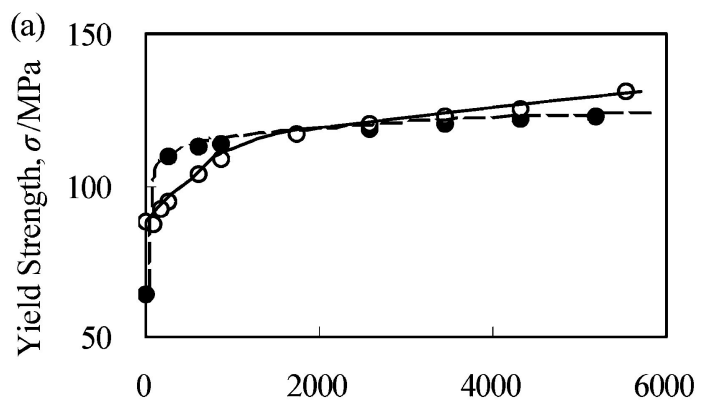

Aging Time, $t / \mathrm{ks}$
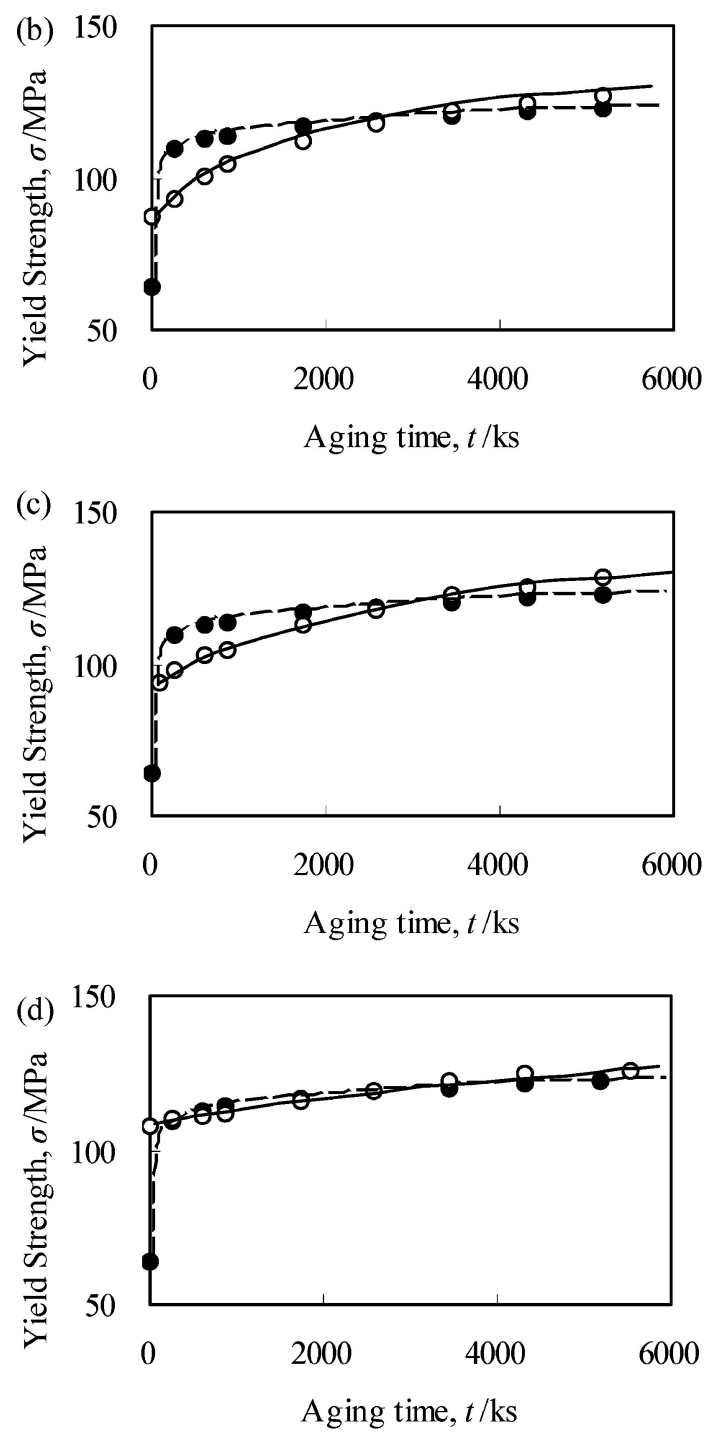

Fig. 4 The aging curve of yield strength at $303 \mathrm{~K}$ after and without pre-aging at $363 \mathrm{~K}$. (a) pre-aging for $7.2 \mathrm{ks}$; (b) preaging for $14.4 \mathrm{ks}$; (c) pre-aging for $21.6 \mathrm{ks}$; (d) pre-aging for $43.2 \mathrm{ks}$. The solid circles and open circles are obtained without and with pre-aging, respectively.

得られた DSC カーブと予備熱処理直後材から得られたそれ を示す．高温クラスタ形成後に $303 \mathrm{~K}$ にて $864 \mathrm{ks}$ 保持した 材料の DSC カーブは, 予備熱処理直後材のそれに比べて, $503 \mathrm{~K}$ での吸熱量が増大し $548 \mathrm{~K}$ での発熱量が減少してい る. $303 \mathrm{~K} に て 1728 \mathrm{ks}$ 保持した材料の DSC カーブは, 503 $\mathrm{K}$ での吸熱量はさらに増大し，548 K での発熱量はさらに減 少している. $503 \mathrm{~K}$ の吸熱量の増大は $303 \mathrm{~K}$ 保持により低

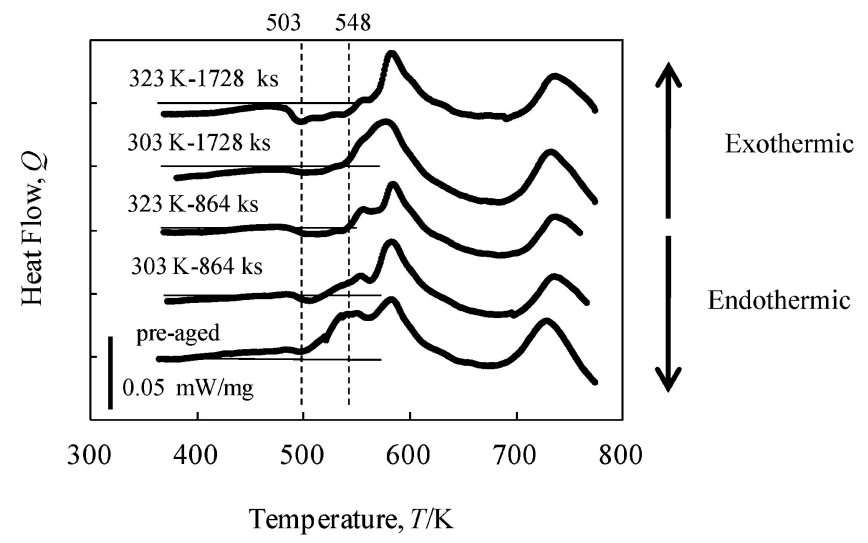

Fig. 5 DSC thermograms of $\mathrm{Al}-\mathrm{Mg}-\mathrm{Si}$ alloy specimens subjected to pre-aged at $363 \mathrm{~K}$ for $21.6 \mathrm{ks}$ (pre-aged) and preaged and isothermally aged at $303 \mathrm{~K}$ for $864 \mathrm{ks}$, at $323 \mathrm{~K}$ for $864 \mathrm{ks}$, at $303 \mathrm{~K}$ for $1728 \mathrm{ks}$, and at $323 \mathrm{~K}$ for $1728 \mathrm{ks}$ after solution heat treatment in a salt bath and quenching.

温クラスタ量が増大したことを, $548 \mathrm{~K}$ の発熱量の減少は高 温クラスタ量が増大したことを示す. $323 \mathrm{~K}$ 保持にて得られ た DSC カーブでも, 予備熱処理直後材の DSC カーブに比 べて, $503 \mathrm{~K}$ での吸熱量は増大し， $548 \mathrm{~K}$ での発熱量は減少 する.したがって，予備熱処理後の $303 \mathrm{~K}$ 保持と $323 \mathrm{~K}$ 保 持では低温クラスタ量と高温クラスタ量がともに増大してい ると言える。

Fig. 6(a)，(c)，(e)はそれぞれ，363 K にて $21.6 \mathrm{ks}$ 保持の 予備熱処理直後の材料, 予備熱処理直後に $303 \mathrm{~K}$ にて 864 $\mathrm{ks}$ ，および $4320 \mathrm{ks}$ 保持した材料の 3DAPにより得られた $\mathrm{Mg}$ 原子と Si 原子の原子マップを示す. Fig. 6(b), (d), (f) は，それぞれ Fig. 6(a)，(c)，(e)の粒子解析後に得られた原 子マップである．粒子解析により，クラスタが明瞭に観察さ れる.これらの粒子解析後のクラスタ構成原子数の平均值と 分布密度を Table 2 に示す。予備熱処理後, $303 \mathrm{~K}$ 保持によ り，低温と高温の両クラスタの構成原子数と分布密度はとも に増大していることがわかる.

予備時効後の $303 \mathrm{~K}$ 保持では高温クラスタが新規に形成 されることはないと考えられるため, DSC 測定で観察され た予備熱処理後の $303 \mathrm{~K}$ および $323 \mathrm{~K}$ 保持材の高温クラス タ量の増大は予備時効時に形成された高温クラスタが $303 \mathrm{~K}$ と $323 \mathrm{~K}$ の保持によりその分布密度を変えずに成長 (構成原 子数が増大)していることを示唆している，それ故，3DAP にて観察されたクラスタの分布密度の増加は低温クラスタの 新規な形成によるものと考えられる。 また，DSC 測定で得 られた低温クラスタ量の保持時間にしたがう増大は，低温ク ラスタが新規形成後に，成長(構成原子数の増大)したことを 示唆する.したがって, 予備熱処理後の室温時効では, 低温 クラスタが新規に核形成し成長するだけでなく，予備熱処理 にて形成された高温クラスタも同時に成長すると考えられる.

以上の検討を踏まえ，予備熱処理後の室温保持中のクラス タの成長挙動を模式的に Fig. 7 に示す。予備熱処理直後で は，予備熱処理にて形成された高温クラスタと固溶 $\mathrm{Mg}$ 原 子々固溶 $\mathrm{Si}$ 原子が存在する。それに続く室温保持では，こ の固溶 $\mathrm{Mg}$ 原子と固溶 $\mathrm{Si}$ 原子は, 予備熱処理にて形成され 
(a)

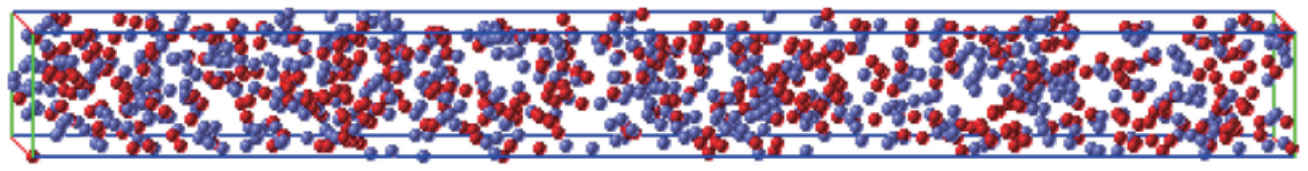

(b)

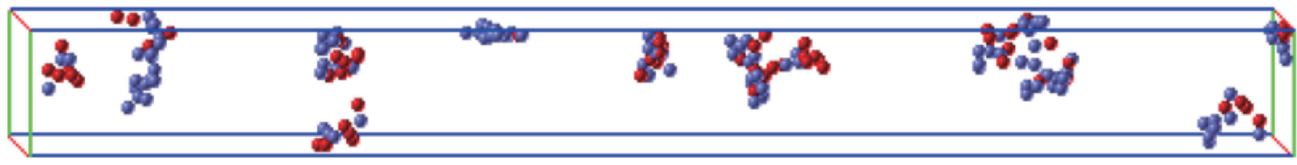

(c)

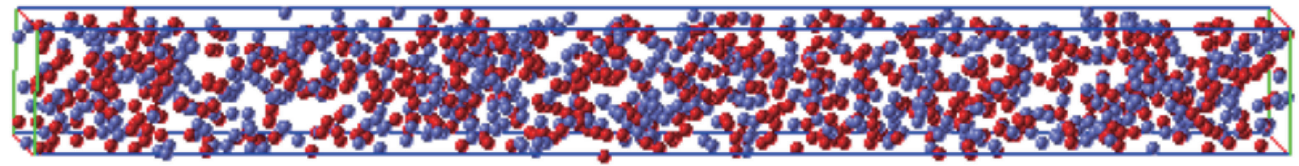

(d)

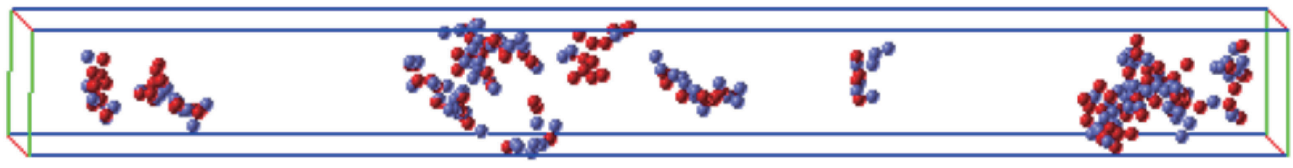

(e)

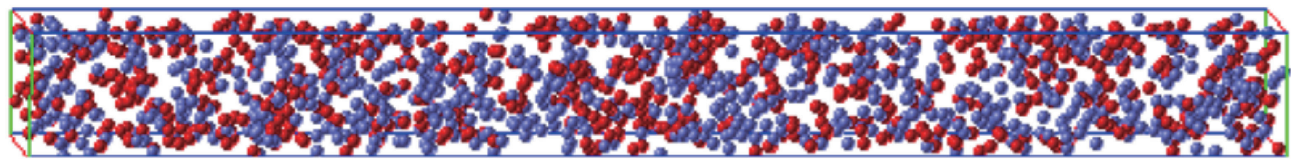

(f)

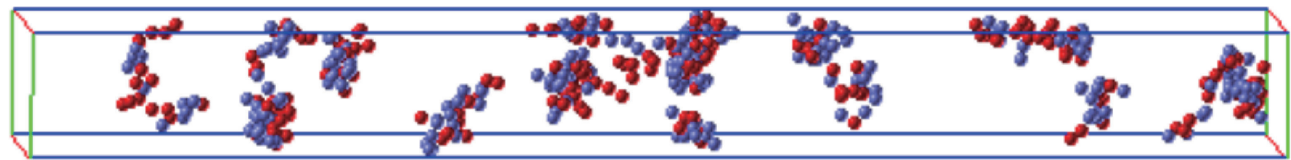

$10 \mathrm{~nm}$

Fig. 6 3D atom maps of $\mathrm{Mg}$ and $\mathrm{Si}$ of specimens pre-aged at $363 \mathrm{~K}$ for $21.6 \mathrm{ks}$. (a), (b) after pre-aging; (c), (d) after additional aging at $303 \mathrm{~K}$ for $864 \mathrm{ks}$; (e), (f) after additional aging at $303 \mathrm{~K}$ for $4320 \mathrm{ks}$; in (a), (c), and (e), all the Mg and Si atoms detected are shown by blue and red points, respectively; and in (b), (d) and (f), only the atoms in the clusters are shown based on the particle analysis $d=1.0 \mathrm{~nm}$ and $N=10$.

Table 2 Number of component atoms of $\mathrm{Mg}-\mathrm{Si}$ clusters and distribution density of the clusters obtained through 3DAP analyses.

\begin{tabular}{ccc}
\hline Aging conditions & $\begin{array}{c}\text { Number of } \\
\text { component atoms }\end{array}$ & $\begin{array}{c}\text { Distribution } \\
\text { density/m }\end{array}$ \\
\hline $\begin{array}{c}363 \mathrm{~K} \text { for } 21.6 \mathrm{ks} \\
363 \mathrm{~K} \text { for } 21.6 \mathrm{ks} \text { followed by 303 K for } \\
864 \text { ks }\end{array}$ & 28 & $4 \times 10^{24}$ \\
$\begin{array}{c}\text { 363 K for 21.6 ks followed by 303 K for } \\
4320 \text { ks }\end{array}$ & 68 & $5 \times 10^{24}$ \\
\hline
\end{tabular}

た高温クラスタと，同時に室温保持にて新規に核形成される 低温クラスタの成長に消費されると考えられる.

4. 結 論

$\mathrm{Al}-0.7 \%$ mass $\% \mathrm{Mg}-0.7$ mass $\% \mathrm{Si}$ 合金を用いて，溶体化 熱処理後の $363 \mathrm{~K}$ での予備熱処理とそれに続く $303 \mathrm{~K}$ およ び $323 \mathrm{~K}$ 保持での 2 段時効処理時のクラスタ形成につい て, 降伏応力の時間変化, DSC, および 3DAP を用いて調 査し，以下の結果を明らかにした。

(1) $363 \mathrm{~K}$ の等温時効では, 時効時間とともに構成原子数 が増大するクラスタの成長が生じる.

(2) $363 \mathrm{~K}$ での予備熱処理後の $303 \mathrm{~K}$ や $323 \mathrm{~K}$ での保持 により降伏応力は上昇する. その時間に対する上昇速度は,

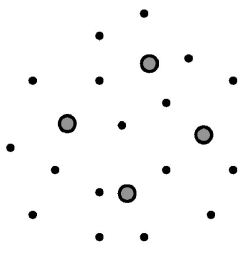

(a)

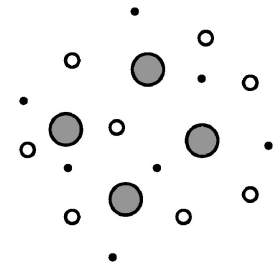

(b)
O High temperature cluster

- Low temperature cluster

- $\mathrm{Mg}, \mathrm{Si}$ atoms

Fig. 7 Schematic illustrations of the formation of high- and low-temperature clusters in the specimens aged at $303 \mathrm{~K}$ following the pre-aging at $363 \mathrm{~K}$ for $7.2 \mathrm{ks}$ in Fig. 4.

(a) pre-aged for $7.2 \mathrm{ks}$, (b) during aging at $303 \mathrm{~K}$ after the pre-aging.

予備熱処理を施さない材料での初期の急激な上昇以降の降伏 応力の上昇速度に比べて大きい.

(3) $363 \mathrm{~K}$ の予備熱処理後の $303 \mathrm{~K}$ と $323 \mathrm{~K}$ の保持では, DSC 測定からは予備時効で形成されたクラスタ量の増大に 加えて $303 \mathrm{~K}$ や $323 \mathrm{~K}$ 保持で観察される別のクラスタ量の 増大も確認され，3DAP 観察からはクラスタの分布密度と構 
成原子数の増大が観察された.

(4) DSC 測定結果と 3DAP 観察結果から，予備熱処理後 の室温保持では, 室温にて形成されるクラスタの新規形成と その成長のみならず，予備熱処理にて形成されたクラスタも 成長すると推察した. 予備熱処理後の室温保持における降伏 応力の増大は，これら両クラスタの成長に起因すると考えら れる。

\section{文献}

1) G. A. Edwards, K. Stiller, G. L. Dunlop and M. J. Couper: Acta Mater. 46(1998) 3893-3904.
2) N. Maruyama, R. Uemori, N. Hashimoto, M. Saga and M. Kikuchi: Scr. Mater. 36(1997) 89-93.

3) M. Murayama, K. Hono, M. Saga and M. Kikuchi: Mater. Sci. Eng. A 250 (1998) 127-132.

4) M. Murayama and K. Hono: Acta Mater. 47(1999) 1537-1548.

5) A. Serizawa, S. Hirosawa and T. Sato: Metall. Mater. Trans. A 39 (2008) 243-251.

6) K. Takata, K. Ushioda and M. Kikuchi: Mater. Sci. Forum 519521 (2006) 233-238.

7) K. Takata, M. Saga, J. Takahashi, K. Ushioda, A. Hibino and M. Kikuchi: Proc. 11th Int. Conf. of Aluminum Alloy, (2008) pp. 961-968.

8) A. J. Ardell: Metall. Trans. A 16(1985) 2131-2165.

9) Gerold V.: Dislocations in Solids, Vol. 4, (North Holland Publ. Co., Amsterdam, 1979) p. 219

10) D. Vaumousse, A. Cerezo and P. J. Warren: Ultramicroscopy 95 (2003) 215-221. 